\title{
Development of Student Worksheet Based Contructivism Approachment to Improving Mathematical Problem Solving Ability
}

\author{
$1^{\text {st }}$ Dini Fajria Trisna \\ Department of Mathematics \\ Universitas Negeri Padang \\ Padang, Indonesia \\ dfajriatrisna@gmail.com
}

\author{
$2^{\text {nd }}$ Hendra Syarifuddin \\ Department of Mathematics \\ Universitas Negeri Padang \\ Padang, Indonesia \\ hendrasy@yahoo.com
}

\author{
$3^{\text {rd }}$ Ratnawulan \\ Department of Mathematics \\ Universitas Negeri Padang \\ Padang, Indonesia \\ ratnawulan320@gmail.com
}

\begin{abstract}
Student worksheet was an important component in learning. Student worksheet used by teachers not yet to be seen developing students' problem solving abilities. Constructivism approach is the learning approach which can trigger the students to build their own knowledge. This research is a development research by using Plomp model. The aim of this study is to understand the characteristics of student worksheet based on constructivism approach. The result showed that student worksheet based on constructivism approach have been valid, practical and effective to improve the ability of student's problem solving.
\end{abstract}

Keywords - student worksheet, Constructivism, Problem solving, Plomp model

\section{INTRODUCTION}

Mathematics is one of the areas of study that had a role in education and studied at every level of education from elementary, junior high school to university. Moreover, the mathematics also serves to solve the problems of everyday life. One obvious example that is often seen is in the process of buying and selling. Mathematics is also required in other disciplines, such as social sciences and natural sciences. Mathematics in school have a goal to be achieved by learners. The purpose of learning mathematics by Permendikbud No. 58 of 2014 regarding curriculum SMP/MTS covers several aspects of ability, namely the understanding of the mathematical concepts, reasoning, and problem solving, communication of ideas / idea, to have an attitude appreciate the usefulness of mathematics in life, an attitude appreciate the usefulness of mathematics in life, performing motor activities that use mathematical knowledge, using simple props as well as the results of the technology to perform the activities of mathematics. Based on these objectives, it appears that the problem-solving ability is an important thing to be possessed of learners in mathematics, because of this ability have a positive impact in the lives of students to solve problems in their daily lives. It is also described by Branca (Purnomo, 2014) that the problem-solving ability is a primary goal in mathematics, and therefore should be given the ability to solve problems, trained and accustomed to students as early as possible.

Hudoyo (1988: 142) also states that teaching problem solving to students, allowing learners become more analytical in making decisions in his life. That is, when learners are trained to solve the problem, then learners will be able to take a decision, because such learners have become skilled on how to collect relevant information, analyze information, and realize how necessary to reexamine the results already obtained. Based on the results of studies conducted by the Program of International Student Assessment (PISA) conducted by the Organization for Economic Cooperation and Development (OECD) or the organization for economic cooperation and development in 2012. In the PISA study results Indonesia is still not able to show even greater success well in the areas of reading, science and mathematics. Indonesia ranks only 64th out of 65 participating countries in the field of mathematics. "Problems in the PISA mathematics more measure problemsolving abilities, reasoning, arguing and communication skills" (Sri and Rumiati, 2011: 51). This shows that the mathematical skills of students in Indonesia is still alarming.

The success of learners in learning is largely determined by instructional tools designed by teachers. Learning tools serve to guide the learning process. The availability of adequate learning tools, will help teachers in implementing the learning process so that the expected goals and learning goals can be achieved. One of the alternative teaching materials that can be used to enable learners in learning is the Student WorkSheet. By using Student Worksheet is expected learners are really active and independent so it can absorb and remember longer to what he learned. Student Worksheet contains things that learners need to know from the questions or issues that the learners need to solve.

Based on the observations at SMPN 1 Padang Gelugur and SMPN 4 Lubuk Sikaping on the learning process undertaken, the learning that happened only one direction only (teacher centered). The learning process is done directly by explaining the subject matter and sample questions. student worksheet provided in the school has not been able to support the learning process that aims to improve the mathematical ability of learners, especially the problem solving ability of mathematical learners. The student worksheet provided generally contains brief information on instructional materials, examples of materials implementation and exercises in the form of multiple choice questions and descriptions. In other words in student worksheet available learners are more emphasized just to develop the ability to count only.

Other problems were found using student worksheet teachers have made their own. student worksheet provided in schools has not been able to support the learning process that 
aims to improve the mathematical ability of students, especially the mathematical problem solving ability of students. student worksheet is provided generally contains brief information about the learning materials, examples of materials and exercises in the form of multiple choice questions and problem descriptions. student worksheet used is also not provide exploratory activities in the form of solving a problem that can guide learners to acquire the concept of the material.

Learners are not able to obtain about is solving problems, so student worksheet no form questions that can be used as an exercise in improving mathematical problem-solving abilities. The student worksheet directly present a brief theory about the subject matter. In other words the student worksheet provided learners with more emphasis only to develop numeracy skills course. As shown in Figure 1.

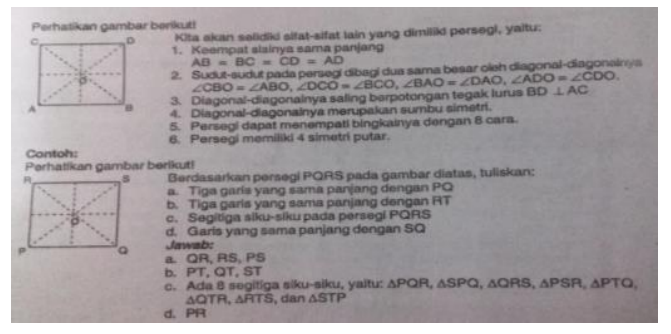

Fig. 1. Example Example Gazette Student Worksheet

Based on Figure 1 student worksheet as it is more emphasis on exercises and yet encourage learners to use their mindset in solving math problems. student worksheet used only making passive learners or receive materials without knowing its usefulness, so student worksheet has not been able to support and facilitate learners to achieve the learning objectives expected.

Learning tools used in teaching as student worksheet should be used as a means of support to facilitate the students to actively participate in learning. The concept was to know the students should not be presented in an instant but is the result of the students' own construction by optimizing the initial knowledge he had. In order for this construction process go easier for the students, the teaching materials used shall be such as to make it more attractive, easily understood and used by learners.

Based on these problems, it needs to be conceived and developed student worksheet that can help the success of the learning process in the classroom. student worksheet developed should be able to facilitate teachers and learners in achieving the goal of learning mathematics, especially mathematical problem solving ability of students. In an attempt to overcome the problems in mathematics learning, it takes a learning device that can support the learning process thereby increasing motivation, activity, understanding and problem solving skills of learners. One alternative that can overcome these problems is to develop a device based on a constructivist approach of learning mathematics.

One approach to learning provides the opportunity for students to construct their own understanding is a constructivist approach. Constructivism as described by Sagala (2009: 88), is the foundation of the philosophy of the contextual approach of which knowledge is built little by little, whose results are expanded through abrupt and non- abrupt contexts. Knowledge is not a set of facts, concepts or rules that are ready to be taken and remembered.

Constructivism holds that knowledge is the acquisition of individuals through active involvement in the learning process. Constructivism learning requires students to actively participate, independent learning abilities, and develop their own knowledge. This is consistent with the opinion of Akhras (2000: 344) which states that "constructivist theories of learning emphasise an active and autonomous role for the learners to construct their own understanding through interacting in an environment in which the knowledge of the domain is not explicitly separated from the context in which it applies".

Muslich in Hosnan (2014: 270) argues "Constructivism is a learning process that emphasizes the development of one's own active, creative and productive understanding based on prior knowledge and meaningful learning experience". According to Jufri (2013: 33) learning with a constructivism approach includes four activities, (1) relating to prior knowledge of students, (2) containing activities of real experiences, (3) social interaction occurring and (4) the formation of a sense of making environment.

So, learning activities with a constructivism approach starting from the initial knowledge of students then the activity must contain activities that have real experience of students so that the occurrence of social interactions that will shape their sensitivity to their environment. This is because in learning constructivism knowledge is built in the minds of students (Bodner, 1968: 1).

In the early stages of learning using constructivism approach, learners are guided to build knowledge of the material to be studied by answering material related questions. Furthermore, learners are helped to express his idea clearly by discussing, writing, drawing, and others to build his knowledge and conclude about the knowledge he has gained. When learners can build their knowledge and understand the concepts that exist in the material, then the material can be attached longer to the memories of learners, so not just memorize but understand the material.

The teacher only acts as a facilitator in the learning process. This puts the teacher as a person who must be able to understand students' thinking. Teachers as constructivists must be able to understand students' thinking psychologically in order to help students engage actively in learning by facilitating students with constructivism learning (Mughal, 2011: 28).

Student worksheet based constructivism contains how learners build their knowledge. student worksheet is made gradually for learners in solving the given problem. Based on the exposure, research will be conducted on the development of constructivism-based learning tools that are expected to make students more active, creative and motivated so that students can solve the problem well. Through learning by using constructivism approach, learners are expected to be really active in learning so as to express their ideas and find their own concepts and principles learned.

Based on the presentation, will do research on the development of constructivism based learning device that is expected to make students more active, creative and motivated so that students can solve the given problem well. 
The formulation of the problem in this research is "how the device characteristics such as lesson plans and learning based on constructivism approach student worksheet valid, practical and effective way to improve mathematical problem solving ability of students in class VII?" The purpose of this study was to determine the characteristics of learning tools such as lesson plans and student worksheet valid based on a constructivist approach, practical and effective way to improve mathematical problem solving ability of students in class VII.

In this study with a constructivist approach, the teacher can provide guidance, directives, statements on student worksheet so as to arrive at a conclusion about the material being taught. student worksheet the teacher depends on the ability of learners and the topic being studied and clarified (Suherman, 2003: 6). Through learning by using a constructivist approach, students are expected to be fully active in the learning so as to tell ideas and find their own concepts and principles learned.

So with this approach, learners are faced with a situation where he is free to discuss, express their ideas, exchange ideas with friends groups and draw conclusions. Teachers act as a guide, he helps learners to use any ideas, concepts, and skills they have learned previously to acquire new knowledge. Filing precise question by the teacher will stimulate the creativity of learners and assist them in finding new knowledge.

In the development of this learning device produced products in the form of student worksheet with product quality in terms of validity, practicality and efective. Validity in development research includes content validity (relevancy) and construct validity (consistency). According to Nieveen (1999), validity leads to the feasibility of instructional tools, both in content and construct. A learning device is said to be valid or feasible to use if the contents and contructs are appropriate and interconnected to facilitate users both teachers and learners.

The validity of student worksheet developed in this study is assessed on the basis of expert assessment, consisting of mathematics education experts, language experts and educational technology experts. Learning tool is valid if the result of student worksheet validation sheet data analysis is in valid category. This development research is done to see the validity of student worksheet math constructivism approach to be used in mathematics learning process.

The level of practicality derived from the response of teachers and students through a questionnaire that is disseminated. In the development of student worksheet to measure effectiveness can be seen from the desire of students using student worksheet in learning. This development research is conducted to see the effectiveness of mathematics learning devices based on constructivism approach to improve students' mathematical problem solving abilities.

\section{RESEARCH METHOD}

This study is a developmental research which used to produce a specific product and test validity, practicality, and effectiveness of these products (Sugiyono, 2011: 407). Research and development is a systematic study to design, develop a product such as programs, approaches, teaching materials, teaching and learning strategies, materials, and so forth.

The development model used in this study is the Plomp model. The Plomp model has three development stages: (1) preliminary research; (2) prototyping phase; and (3) assessment phase. The steps of the learning device development plan above can be detailed as follows:

\section{A. Preliminary Research}

At this stage, identification or analysis of what is needed for Student Worksheet development is based on constructivism approach. The purpose of this phase is to define the requirements for the development of Student Worksheet. At this stage, there are four main steps undertaken by the researcher: (a) Needs analysis; (b) curriculum analysis; (c) Analysis of concepts; and (d) Analysis of learners.

\section{B. Prototyping Phase}

This stage is used to design student worksheet based on constructivism approach by using information that has been obtained at preliminary research stage. At this stage, the main steps undertaken by the researchers are: (a) Self evaluation, is a self- correction by researchers to student worksheet after it be designed. Once revised, the result is called prototype 1; (b) expert review, is a correction of student worksheet conducted by some pre-determined experts. After being revised and declared valid, the result is called prototype 2; (c) One to one evaluation, an evaluation of student worksheet conducted by individuals with different levels of ability. Once revised, the result is called prototype 3. (d) Small group evaluation, an evaluation of student worksheet conducted by 6 students with different levels of ability. After the revision, the result is called prototype 4 .

\section{Assessment Phase}

Every stage of assessment tested to test the effectiveness of the resulting product field test in grade VII SMPN 4 Lubuk Sikaping to see the practicality and effectiveness. The data was collected through validation sheet, teacher's and student's response questionnaire, observation sheet of implementation, and the result of students' reasoning ability test.

Based on the research methods that have been described previously, the development carried out in this study only focuses on the process of validation stages of student worksheet.

\section{RESULT AND DISCUSSION}

\section{A. Preliminary Study}

At this stage, identification or analysis required for the development of a constructivism approach based on learning tools. This phase is done by analyzing the objectives within the limits of the subject matter that will be developed.

\section{1) Results of Needs Analysis}

Based on observations and interviews conducted to teachers of mathematics grade VII SMPN 4 Lubuk 
Sikaping, we obtained some informations, namely: in the learning process of mathematics, teachers often use; the conventional learning because it consumed time effectiveness; and learning sourcess, such as textbooks and Student Worksheet. Student Worksheet helped the learners to practice doing mathematics problems in school or at home, but it did not able to optimize problem-solving skills in mathematics. The material in student worksheet is served both directly, and briefly and is not accompanied by the process of finding, it did not facilitate learners to construct their knowledge.

The further information that we obtained is about the students understanding on studied material. According to the teachers, the ability of learners was very diverse. The understanding of the material depends on the interest and attention of learners during the learning process. Some obstacles are found during the learning process; (1) many students have a lack knowledge on the basic concepts of mathematics; (2) many students think that mathematics is difficult; (3) many formulas that are less attracted the learners to learn; (4) lackof the courage to ask about the subject matter because they feel shame and fear of being wrong to ask questions.

In order to produce a fun and effective learning process for students we developed student worksheet to improve student activities and problem solving skills. In addition, student worksheet should also contain commands or questions that guide the students to find their own mathematical principles/ and to enable the students to practice what they have found. it could motivated the students to participate in the learning and facilitate students to construct knowledge independentlyhence hopefuly the learning is more meaningful.

\section{2) Curriculum Analysis Results}

This analysis in the form of determination of indicators on materials Linear Equations and Inequalities One variable that will be developed lesson plan and its student worksheet. Translation of KI, KD and indicators of achievement of competencies into consideration to determine the necessary concepts in mathematics learning and measure achievement of KI and KD.

\section{3) Concept Analysis Results}

The analysis was based on curriculum which used concept that consisted 4 chapters; the number, the set, the algebra and the linear equations and inequalities of one variable.

\section{4) Results of Student Analysis}

Information gathering is done by interviewing teachers and filling in questionnaires by students. The results of interviews with teachers obtained information that students have varying academic abilities, including high ability, moderate and low. The questionnaire results show that students consider mathematics a useful lesson for everyday life, but students have difficulty solving and solving problems in story form. Students prefer learning activities in groups. This is in line with the student questionnaire results indicating that as many as 20 out of 30 students prefer learning by group learning. This character indicates that students prefer to do an activity together. Students are more dominant in favor of learning sources (student worksheet) that are orange and green with A4 paper size and accompanied by interesting drawings in accordance with the material, the application of stages or steps of learning are detailed and clear, so students in groups can find and understand the current material well studied, and if students are having trouble the teacher is ready to help.

Based on a needs analysis, curriculum analysis, analysis of the concept and analysis of learners, then designed a constructivist approach based learning tools are suitable for application in class VII semesters 1. Prototyping phase is the stage of software design. This learning device is designed based on the characteristics of a constructivist approach based learning.

\section{B. Results Prototyping Phase (design prototype)}

\section{1) Designing Student Worksheet}

Student worksheet designed and developed referring to the characteristics of the constructivist approach. Student worksheet designed to help students to construct, find themselves new knowledge related to learning material based on the indicators of achievement of competencies. Student worksheet size adapted to the size student worksheet used students are HVS A4 size. Student worksheet presentation consists of student worksheet usage instructions, Basic Competency, indicators and objectives.

Student worksheet presentation includes: cover page/cover, writing and drawing. The cover page /cover contains the identity or title "Worksheet Students Constructivism-Based Approach" and contained the words "Math" as the subject's identity, an identity column as the owner student worksheet learners. Sections cover served with shades of orange and green. On the cover there is also a description student worksheet to class VII Semester 1, and the identity of the author. In addition, there is a section of identity required by students is the column name, grade and school.

Type face used for the name of the author on the cover of this student worksheet namely Centuri created using WordArt font size 20. Posts student worksheet title created using WordArt typeface Traditional Arabic size 24.inscription "Based Constructivism" created using type face Corsiva Monotype size 26 and black. The inscription on the identity column students using type face Corsiva Monotype size 22. The article "Mathematics" created by typeface Berlin Sans FB Demi is 70 and black. Writing "SMP VII Semester 1" was created using type face the Baskerville Old Face size 24. Writing and Mathematics Education at the University of Padang posts created using WordArt to the type of paper Cerokee Plantagenet measuring 20 and brown. There is the epitome of Universitas Negeri Padang on the top. Section titles and sections that need more emphasis is given striking colors. student worksheet cover design based on constructivism approach can be seen in Figure 2 . 


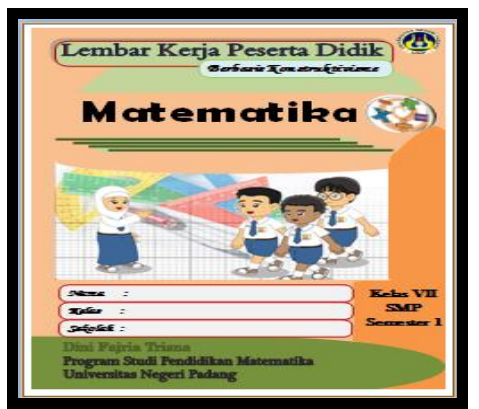

Fig. 2. Cover Design on Student Worksheet Example

In student worksheet there are also instructions for using student worksheet. Section instructions for use contain things that must be considered before using student worksheet learners. Background color used is white. Writing "Instructions for Use student worksheet" designed typeface Bluenoon size 28 and blue. Instructions for use written in a box shading with a dotted line is green and the font Comic Sans $M S$ size 12, to make writing look neater and clusters are numbered and use left-right price (Justify). Design instructions for use can be seen in Figure 3.



Fig. 3. Design Instructions for Use Student Worksheet

Learning activities in student worksheet begins with illustrations / drawings that exist in the daily life of students. Students will build on their new knowledge based on prior knowledge. Where at the beginning of student learning is given a problem or statement. Through this problem, students are interested to understand and try to find solutions to the problems given so that students can build their understanding. This activity is called orientation.

Ayo Kita amati
Nadia : "Izah, coba jawab pertanyaanku. Siapakah presiden pertama Republik
Indonesia?"
Azizah : Saya tahu Nad. Presiden pertama Republik Indonesia adalah Ir.
Soekarno."
Nadia : "Betul."
Azizah : "Sekarang giliran saya. Siapakah pencipta lagu Indonesia Raya?"
Nadia : "Pencipta lagu Indonesia Raya adalah Kusbini."

Fig. 4. Orientation

Furthermore, students are welcome to sit in their respective groups that have been determined and ordered to answer questions on student worksheet in order to construct knowledge independently of the material students will learn in groups organize, process, organize and analyze the data provided. This activity is called elicitation. An example of elicitation on student worksheet 1 can be seen in Figure 5 .

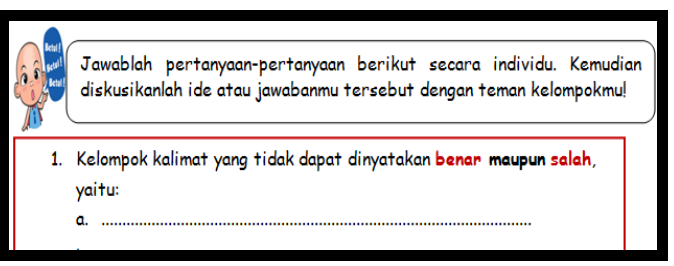

Fig. 5. Example Elicitasi on Student Worksheet 1

After sitting on a group that has been subdivided, students are guided to discuss with the group in preparing, processing, organizing and analyzing data from a given problem through a series of questions. This question to develop his ideas about the material that has been studied by a discussion in order to acquire new knowledge. This is called the idea of restructuring activities.

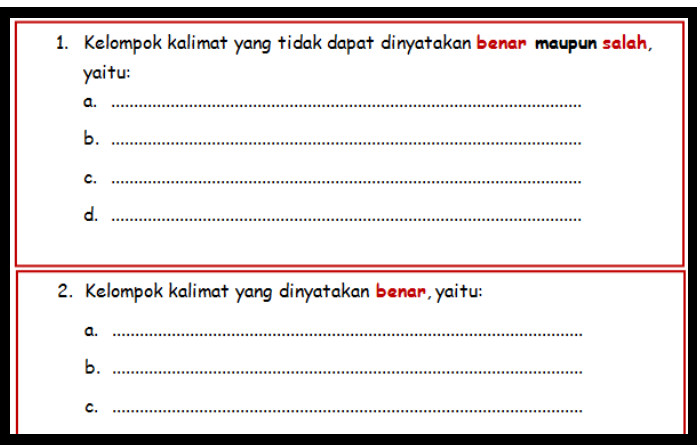

Fig. 6. Restructuring Idea

After students complete the discussion, the students to write their results or understanding of the material after following a learning experience that is expressed in the conclusions. At this stage the student to apply the knowledge they gained in the execution of a practical exercise.

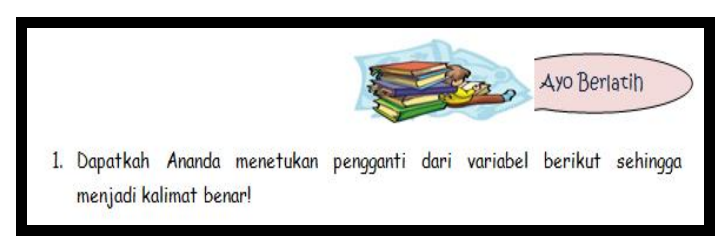

Fig. 7. Application Idea

Furthermore, students are led to conclude in general materials and learning outcomes that have been made for using student worksheet based constructivism approach.

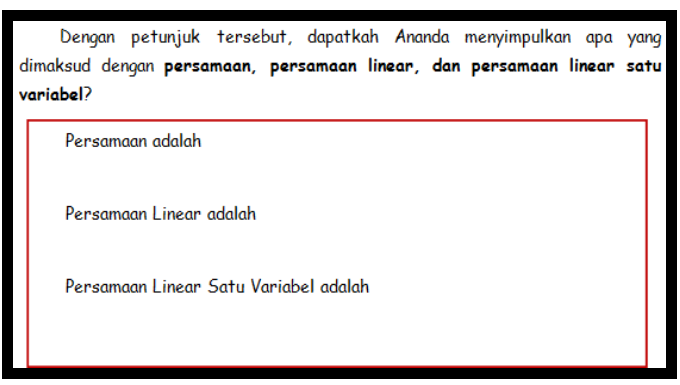

Fig. 8. Review

On student worksheet students are also given homework to deepen the materials that have been studied. 
Examples of homework on student worksheet can be seen in Figure 9 .



Fig. 9. Display Homework

After learning tool designed to do self evaluation to see typing errors, correct use of punctuation, the accuracy of the size of text, pictures and illustrations relevance given, empty space availability to answer questions later corrected and validated to experts competent in their respective fields.

\section{2) The results of the evaluation itself (Self-Evaluation)}

The first activity undertaken after designing the learning device is examined by the researchers. Prior to discuss with the experts, conducted self-evaluation prior to the learning tools that have been designed. In general, the error of $1-5$ is almost the same student worksheet many errors in punctuation and typing accuracy. Errors on student worksheet one of which is in typing the capital letter at the beginning of the sentence and the lack of letters in a word and an error in the use of words such as "you", supposedly said, "Ananda". One example can be seen in Figure 10.

\section{Before Revision}

Perlu kamu ketahui, kalimatkalimat diatus tidak dapat ditentukan nilai kebenarannya, karena ada unsurunsur yang belum dikctahui. Seperti pada kalimat (a) ada unsur $X$ yang belum dikctahui, begitu jugga denngan kalimat tainnya.

Dapatkah (tamum menuliskan pengganti setiap unsur yang belum diketahui dan berikalah alasnmul

\section{After Revision}

\section{Perhatikan kalimat (a) terdapat unsur $x$ yang belum diketahui, begitu juga dengan kelimat lainnya. Dapatker Anandegmenulisken pengeganti setiop unsur yang belum diketehui tersebut.}

Fig. 10. Phase Error Footage Self

\section{3) Validation learning device by Expert (Expert Review)}

During the validation process, there are several revisions suggested by the validator. In addition to providing some advice, validator also assess the student worksheet which has made researchers. After the repair is done, the validator gives an assessment of the student worksheet. student worksheet validation results based on constructivism approach on all aspects of the general validity of the didactic aspects, aspects of language and aspects kegrafikan already valid criteria with an average of consecutive validity index is $0.820 ; 0.867$ and 0.857 . Overall validity student worksheet based constructivist approach already valid criteria with an average of 0,848 overall validity index.

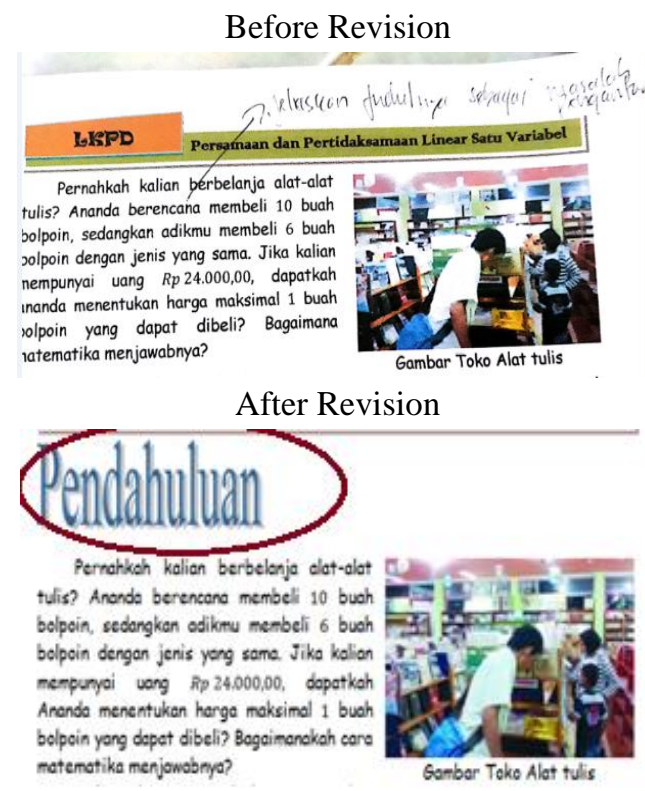

Fig. 11. Advice Against Validator Student Worksheet By Expert

\section{4) One-to-one Evaluation}

Based on the evaluation of a person's interviews show that student worksheet used on the difficulty level is in conformity with its ability to junior high school. The given problem is not too difficult nor too easy. In terms of systematic delivery of content has been structured so that learners are quite easy to understand the material on student worksheet. Student worksheet used in terms of ease of use, readability and presentation as well as the time spent in practice. The clarity of the instructions and the issues presented in the overall student worksheet clear. Learners also deliver, and display color design that tends student worksheet brightly colored and lightweight making learners interested to read and understand it. The questions contained in student worksheet accordance with the level of ability of learners.

Based on the evaluation of the implementation details of this individual, the general revision only in the sentences. Researchers make improvements based learning tools constructivist approach to learning devices get better again. Results repair devices based learning problemsolving approach is called a prototype 3 . Furthermore, after the evaluation of individuals is tested on a small group.

One of the samples of the individual evaluation phase can be seen in Figure 12.

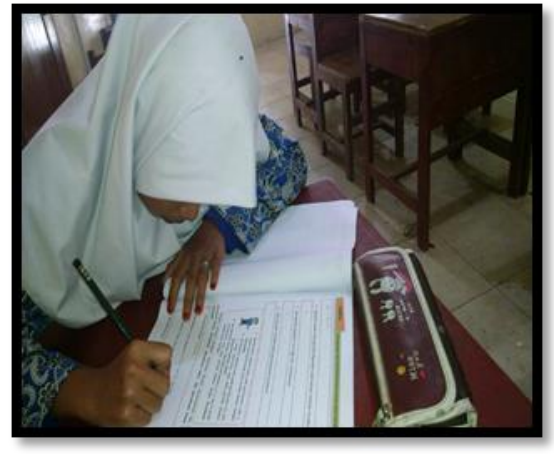

Fig. 12. Implementation of One to One Evaluation Phase 


\section{5) Small Group Evaluation}

The results of the analysis of interviews with learners shows that they enjoy learning by using student worksheet based constructivism approach. In terms of ease of use, student worksheet easy to use, learners can better understand learning materials using student worksheet. In terms of legibility, learners can easily understand the language used in student worksheet so that he can imagine the problems and work orders or answer questions at student worksheet. The activities that exist in student worksheet interesting, the presentation of pictures and illustrations on student worksheet easier for them to understand the concept of the material they are learning. Learners are less accustomed to his opinion, if the student worksheet there is a command that asks students to put forward reasons then, they will experience confusion. In addition, learners are also less familiar in solving troubleshooting. Revisions were made on time and the addition of equipment / materials required to perform student worksheet. One snippet of small group stage implementation can be seen in Figure 13.

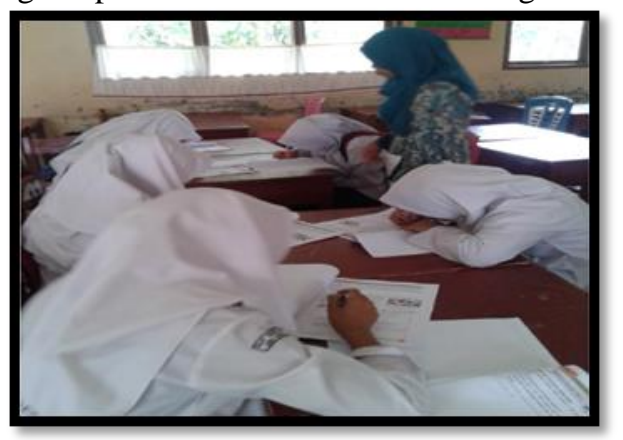

Fig. 13. Implementation of Small Group Evaluation Phase

\section{Results Assessment Phase}

1) Student Worksheet Practical Based on Constructivism Approach

Practicalities Questionnaire given to students VII.1 grade SMPN 4 Lubuk Sikaping after following mathematical student worksheet based learning using the constructivist approach stage field test. Based on analysis of questionnaire responses of students during the field test, followed by 30 students obtained an average value of the practicalities of every aspect in the range $69.75 \%$ to $100 \%$, which is in the category is quite practical, practical and very practical.

The overall average value practicality student worksheet obtained from a questionnaire of students is $80.25 \%$ with a practical category based on the criteria of practicality.

Student worksheet practicalities and lesson plan Questionnaire given to the seventh grade mathematic teacher at SMPN 4 Lubuk Sikaping after learning implemented. Based on the analysis of the results of questionnaire responses of teachers to student worksheet percentage for every aspect, ranging from $75 \%$ to $100 \%$ for the category of practical and very practical. In general, the average results of questionnaire responses of teachers to the constructivist approach based device is $87.50 \%$ categorized as very practical.

\section{2) The Effectiveness of Student Worksheet Based on Constructivism Approach}

Effectiveness of mathematics learning device seen from the test results of mathematical problem solving ability of students after learning by using math-based learning tools constructivism approach. Before the end of the test conducted on a class field test, this final test items tested before hand in a different class to see the validity, distinguishing, difficulty index. Trial question final test was conducted in a different class, namely the class VII. 3 totaling 30 students. Based on test results obtained all valid questions, distinguishing good and difficulty index revision.

After the end of the test item is tested on different classes and because revised, then conducted final tests on the class of the field test. The effectiveness of the device is a constructivist approach based learning is also seen from the acquisition of test scores mathematical problem solving ability of students.

Based on the analysis of mathematical problem solving ability test above were obtained an average percentage of $77.68 \%$, with both categories. It can be concluded that the device is a constructivist approach based learning effective to improve the mathematical problem solving ability of students.

\section{CONCLUSIONS AND SUGGESTIONS}

This research is a development research that produces student worksheet based on constructivism approach. Based on the research that has been done, it can be concluded that (a) student worksheet development process based on constructivism approach of class VII SMP students on material of linear equality and inequality one variable is implemented with Plomp development model consisting of three phases: initial investigation phase, development phase and assessment phase. Based on the development process that has been implemented, the results obtained in the form student worksheet constructivismbased approach of students class VII SMP has been valid both in terms of content and construct, practical both from the aspect of implementation, ease and time required, effectively improve students' mathematical problem solving skills

There are several things that researchers can suggest based on the conclusions of this research that is, (a) to be used by teachers of mathematics as an alternative learning device in learning equations and linear inequalities of one class VII SMP, (b) It is expected that there is further testing at other schools to see widespread practice and effectiveness of the developed student worksheet, and (c) For other researchers who will continue this research, it is advisable to innovate in subsequent research such as development of student worksheet mathematics for other materials or innovation of new mathematics learning tools.

\section{ACKNOWLEDGMENT}

With the completion of this research, the researcher would like to thank Mr. Drs. Hendra Syarifuddin, M. Si, Ph.D and Ms. Ratnawulan, M.Si and lecturers of PostGraduate of Universitas Negeri Padang who have provided guidance with sincere heart and patience in completing this 
journal. This journal is prepared based on the thesis Dini Fajria Trisna entitled Development of Student Worksheet Based Contructivism Approachment to Improving Mathematical Problem Solving Ability.

\section{REFERENCES}

[1] Akhras. Fabio N and John A. Self, "System Intelligence in Construktivist Learning", International Journal of Artificial Intelligence in Education, 2000, 11,344-376.

[2] Bodner. G.M., "Constructivism: A Theory of Knowledge", Journal of Chemical Education, 1986, 63, 873-878.

[3] Hosnan. M., Pendekatan Saintifik dan Kontekstual dalam Pembelajaran Abad 21, Bogor: Ghalia Indonesia, 2014.

[4] Hudoyo. H, Mengajar Belajar Matematika. Jakarta: Departemen Pendidikan dan Kebudayaan Direktorat Jenderal Pendidikan Tinggi Proyek Pengembangan Lembaga Pendidikan Tenaga Kependidikan, 1988.

[5] Jufri. Wahab, Belajar dan Pembelajaran Sains. Bandung: Pustaka Reka Cipta, 2013.

[6] Mughal. Farooq and Aneesa Zafar, "Experiential Learning from a Constructivist Perspective: Reconceptualizing the Kolbian Cycle", International Journal of Learning and Development, (Online), Vol. 1, No. 2, 2011, (http://eprints.lancs.ac.uk/62024/1/952.pdf, diakses 22 September 2016)

[7] Nieveen. Nienke, Design Approaches and Tools in Education and Training. Netherlands: Kluwer Academic Publishers, 1999.
[8] Plomp. Tjeerd, An Introduction to Educational Design Research: SLO - Netherlands Institute for Curriculum Development, 2013.

[9] Plomp. Tjeerd dan Neinke Nieveen, Educational Design Research, Part A: An Introduction, Enchede: SLO, 2013.

[10] Peraturan Menteri Pendidikan Nasional Nomor 22 Tahun 2016 tentang Standar Proses, Jakarta: Kemendikbud, 2016.

[11] Peraturan Menteri Pendidikan Nasional Nomor 58 Tahun 2014 tentang Kurikulum SMP, Jakarta: Kemendikbud, 2013.

[12] Purnomo, Eko Andy dan Venissa, Peningkatan Kemampuan Pemecahan Masalah Melalui model Pembelajajaran ideal Problem Solving Berbassis Project Based Learning, 2014, ISSN: 2339-2444, Online, (accessed 8 Januari 2017).

[13] Sagala. Syaiful, Kemampuan Profesional Guru dan Tenaga Kependidikan, Bandung: Alfabeta, 2011.

[14] Sri Wardhani dan Rumiati, Modul Matematika SMP Program Bermutu: Instrumen Penilaian Hasil Belajar Matematika SMP Belajar dari PISA dan TIMSS. Yogyakarta: Retrieved from PPPPTK Matematika (p4tkmatematika.org), 2011, (Accessed 20 Agustus 2016)

[15] Sugiyono, Metode Penelitian Pendidikan, Bandung: CV. Alfabeta, 2011.

[16] Suherman. Erman, dkk., Strategi Pembelajaran Matematika Kontemporer, Bandung: Fakultas Pendidikan MIPA Universitas Pendidikan Indonesia, 2003. 